\title{
A ATUAÇÃO DE MARCO FELICIANO NA COMISSÃO DE DIREITOS HUMANOS E MINORIAS (CDHM)
}

\author{
Rafael Bruno Gonçalves*
}

\begin{abstract}
RESUMO
Durante a 54 . Legislatura da Câmara dos Deputados (2011-2015), parlamentares evangélicos justificavam que a presença de Marco Feliciano na CDHM representava uma luta do bem contra o mal, situação que exigia o discernimento dos inimigos e a articulação de diferentes estratégias discursivas. O objetivo deste artigo é apresentar, à luz da análise do discurso, as distintas posições de parlamentares evangélicos e não evangélicos nos momentos de defesa e de crítica sobre a eleição de Marco Feliciano. O artigo também pretende abordar as desavenças que ocorreram durante o pleito de Feliciano, bem como, os impactos e as primeiras ponderações que surgiram diante da experiência singular de um evangélico exercendo o cargo de presidente da Comissão de Direitos Humanos na Câmara.

Palavras-chave: Evangélicos. Câmara dos Deputados. Direitos Humanos. Discurso.
\end{abstract}

\section{THE PERFORMANCE OF MARCO FELICIANO AT THE COMMISSION ON HUMAN RIGHTS AND MINORITIES}

\begin{abstract}
During the 54th Legislature of the Chamber of Deputies (2011-2015), evangelical parliamentarians justified that the presence of Marco Feliciano in the CDHM represented a fight for good against evil, a situation that required the discernment of enemies and the articulation of different discursive strategies. The objective of this article is to present, in the light of the analysis of the discourse, the different positions of evangelical parliamentarians and non - evangelical in the
\end{abstract}

* Possui doutorado em Sociologia (2016) pelo Instituto de Estudos Sociais e Políticos (IESP), da Universidade do Estado do Rio de Janeiro (UERJ), com período sanduíche (2015) na Universitat Autònoma de Barcelona (UAB). Atua como professor na Universidade Federal do Pampa - UNIPAMPA. 
moments of defense and criticism on the election of Marco Feliciano. The article also intends to address the disagreements that occurred during the Feliciano tenure, as well as the impacts and the first considerations that arose from the unique experience of an evangelical exercising the position of president of the Human Rights Commission in the Chamber.

Keywords: Evangelicals. Chamber of Deputies. Human Rights. Discourse.

\section{LA ACTUACIÓN DE MARCO FELICIANO EN LA COMISIÓN DE DERE- CHOS HUMANOS Y MINORÍAS (CDHM)}

\section{RESUMÉN}

Durante la 54 a Legislatura de la Cámara de Diputados (2011-2015), parlamentarios evangélicos justificaban que la presencia de Marco Feliciano en la CDHM representaba una lucha del bien contra el mal, situación que exigía el discernimiento de los enemigos y la articulación de diferentes estrategias discursivas. El objetivo de este artículo es presentar, bajo la luz del análisis del discurso, las diferentes posiciones de parlamentarios evangélicos y no evangélicos en los momentos de defensa y de crítica sobre la elección de Marco Feliciano. El artículo también pretende abordar las desavenencias que ocurrieron durante la gestión de Feliciano, así como los impactos y las primeras ponderaciones que surgieron ante la experiencia singular de un evangélico ejerciendo el cargo de presidente de la Comisión de Derechos Humanos en la Cámara.

Palabras clave: Evangélicos. Cámara de los Diputados. Derechos Humanos. Discurso.

\section{INTRODUÇÃO}

A eleição do pastor Marco Feliciano (PSC-SP) para a presidência da Comissão de Direitos Humanos e Minorias (CDHM) durante a $54^{\text {a }}$.

Em 2008, Feliciano fundou a sua própria igreja em Orlândia, a Assembleia de Deus Catedral do Avivamento. Nessa denominação, acumula as funções de pastor e presidente do Ministério. Contudo, antes de criar a sua própria igreja, Feliciano tentou tornar-se pastor da Assembleia de Deus em Belém. A sua tentativa tornou-se frustrada no momento em que lideranças da igreja perceberam que Feliciano já desempenhava a função de pastor em outra denominação, o que é considerado uma espécie de estelionato religioso. 
Legislatura, representou um dos momentos de maior polarização entre boa parte da Frente Parlamentar Evangélica (FPE) e congressistas que não compõem a frente. Antes de serem destacados os conteúdos das seções deste artigo, é necessário entender as razões que levaram esse segmento religioso a disputar a presidência da CDHM, assim como o impacto ocasionado com a eleição e a consequente gestão do pastor Marco Feliciano frente à comissão. As consequências geradas saíram da esfera legislativa federal e adentraram em outros campos, por exemplo, por meio da divulgação de manifestos de organizações, intervenções de ativistas que atuam na defesa dos direitos humanos, comunidades religiosas, movimentos sociais, e outros agrupamentos que representavam a sociedade civil organizada.

A eleição de Feliciano também teve uma forte exposição midiática, com a cobertura das sessões da CDHM, das atividades que reivindicavam a permanência e a saída de Feliciano, ambas com comentários de especialistas sobre o cenário político e as consequências que acarretariam acerca da discussão dos direitos humanos na Câmara dos Deputados, em uma comissão dirigida por um parlamentar evangélico que esteve envolvido, pouco antes da eleição, em torno de assuntos polêmicos contendo comentários racistas, machistas e homofóbicos. ${ }^{2}$

A candidatura de Feliciano para a CDHM já eclodiu de forma polêmica. Com as críticas advindas de diversos setores que reivindicam as pautas dos direitos humanos, coube aos parlamentares da FPE se colocarem no papel de vítimas. Nas ocasiões em que utilizaram o Plenário da Câmara para tratar do assunto, ou durante as sessões na CDHM, deputadas e deputados recorreram ininterruptamente aos discursos vitimizados, identificando os adversários no jogo político, em outras palavras, os outros dentro dessa ordem relacional. Seguindo o referencial teórico de Chantal Mouffe (2007, 2012, 2014), esses outros irão constituir

Os conteúdos desses comentários proferidos pelo pastor Marco Feliciano serão expostos detalhadamente mais adiante neste artigo, contudo, resumida e respectivamente, essas polêmicas estão relacionadas às seguintes opiniões de Feliciano: sobre a África - o deputado afirmou que, de acordo com a Bíblia, os africanos descendem de ancestrais amaldiçoados; a respeito das mulheres - Feliciano comentou que é contra a luta das mulheres pela igualdade de direitos, pois essa igualdade levaria a humanidade ao seu fim e, com relação às declarações homofóbicas - Feliciano asseverou que a AIDS é um câncer gay. 
o polo agônico que, também, em diversos momentos, passaram a ser identificados pelos evangélicos na CDHM como polo antagônico.

A comissão começou a ser representada majoritariamente por deputadas e deputados vinculados à Igreja Assembleia de Deus, tendo parte destes parlamentares se mostrado intolerantes diante das tentativas de diálogo que outras/os deputadas/os da comissão empreendiam para tentar reverter a situação, por exemplo, por meio da sugestão para a nomeação de outro parlamentar do PSC para a presidência da CDHM que não estivesse envolvido em torno de temas polêmicos. ${ }^{3}$ Apesar dos esforços de alguns deputados e deputadas e da mobilização de setores da sociedade que reivindicam a pauta dos direitos humanos, Marco Feliciano foi eleito presidente da CDHM no dia 7 de março de 2013 e exerceu o cargo até o dia 26 de fevereiro de 2014. Nas eleições gerais de outubro do mesmo ano, Feliciano foi reeleito como deputado federal.

O presente artigo está estruturado da seguinte forma: a primeira seção focalizará a teoria do discurso elaborada por Chantal Mouffe e Ernesto Laclau. A segunda seção pretende delinear algumas contribuições provenientes da sociologia da religião que buscam tratar de questões como o pluralismo religioso, o fundamentalismo e a laicidade. A terceira seção abordará com maiores detalhes a chegada de Marco Feliciano na Câmara dos Deputados, a eleição para a presidência da CDHM, as polêmicas que ocorreram em torno do pleito, as resistências e os apoios oriundos de denominações religiosas e não religiosas e também os impactos e principais ponderações sobre a experiência inusitada de um evangélico exercendo a presidência da CDHM. A quarta seção exibirá as matérias sujeitas à deliberação na CDHM durante a gestão de Marco Feliciano, o conteúdo dessas proposições, a autoria e a situação em que se encontram. A quinta seção constituirá o espaço da realização da análise discursiva, destacando os pronunciamentos identificados nas sessões plenárias da Câmara e também durante as reuniões da CDHM, assim como, de assuntos notáveis e das estratégias discursivas. Esses momentos regimentais evidenciarão o acirramento das disputas internas

Durante o processo, alguns parlamentares sugeriram que a deputada Antônia Lúcia (PSC-AC) ocupasse a presidência da $C D H M$, o que evidentemente não ocorreu em virtude da relutância dos membros evangélicos da comissão. 
e a intensidade dos conflitos entre defensoras(es) e opositoras(es) de Marco Feliciano. Por fim, serão realizadas as considerações finais sobre a chegada de Feliciano na CDHM e os impactos causados no cenário político institucional.

\section{TEORIA DO DISCURSO}

A teoria do discurso de Chantal Mouffe e Ernesto Laclau, também chamada teoria da hegemonia, pós-estruturalista ou pós-marxista, pode ser considerada uma nova forma de pensamento sobre o tratamento de algumas questões clássicas como a caracterização do social e do político. Em termos de análise, a autora e o autor argumentam que estamos diante de uma fragmentação de elementos, todos dispersos, cabendo assim a uma estrutura discursiva, chamada de prática articulatória, estabelecer a unidade entre esses elementos. O discurso é o que tem essa capacidade de estabelecer a união entre os diferentes elementos fragmentados. Em Nuevas reflexiones sobre la revolución de nuestro tiempo (1993) Laclau determina o conceito como:

Esta totalidade que inclui dentro de si o linguístico e o extralinguístico é o que chamamos discurso. Em um momento justificaremos esta decisão; porém o que deve estar claro desde o começo é que por discurso não entendemos uma combinação de fala e escritura, e sim, pelo contrário, a fala e a escritura são somente componentes internos das totalidades discursivas (Ernesto LACLAU, 1993, p. 114).

A passagem citada pretende esclarecer o que é denominado como discurso. Ele não se constitui apenas no momento da fala, ou do gesto, mas parte de ambos, inseridos desde já dentro do âmbito de uma totalidade. A noção de significado é extremamente importante na lógica discursiva. Segundo Laclau, toda configuração social é uma configuração significativa (Ernesto LACLAU, 1993, p.114), assim, atribuímos diferentes significados a um mesmo acontecimento.

Para Laclau e Mouffe, todo objeto se constitui em um objeto de discurso (Ernesto LACLAU \& Chantal MOUFFE, 1987, p.179). Dentro de uma estrutura discursiva, o discurso não revela apenas um caráter 
mental, mas também material, ele é capaz de estabelecer a união entre os gestos e as palavras, assim, todo discurso é uma prática discursiva.

Essa capacidade de unir diferentes palavras e ações demonstra todo o caráter complexo da categoria de discurso porque nem sempre os diversos elementos que aparecem no momento da produção de sentido são explícitos, é preciso captar suas diferentes formas de união. O conceito de discurso de Mouffe e Laclau, desse modo, propõe abarcar todas essas complexidades que surgem, mesmo aquelas difíceis de perceber em um primeiro momento. Esse discurso está fixado em uma totalidade que apresenta toda a sua precariedade e contingência. Todos os sentidos são provisórios nas relações discursivas estabelecidas. Assim, os discursos nunca estão acabados e centralizados, seus sentidos são continuamente construídos nas mais diversas situações. O que motiva essas construções é o funcionamento das práticas articulatórias que, segundo a autora e o autor, estabelecem relações entre os elementos distintos os quais não estão previamente articulados.

Com relação a esse exercício teórico, é importante destacar que ainda são escassos os estudos que utilizam a análise do discurso para investigar a participação dos evangélicos na política. Esta é uma das razões deste artigo, ou seja, o exercício de colocar em prática esse aporte derivado da teoria do discurso de Laclau e Mouffe na análise do comportamento discursivo dos evangélicos.

Sobre os subsídios teóricos desses autores, um conceito que merece destaque para os fins desta análise é a definição de antagonismo. Vale lembrar que este é um conceito derivado não apenas do antagonismo de classe, mas das diferentes relações antagônicas que se estabelecem em vários planos do social. A realidade do social é repleta de diferenças discursivas e, nesse aspecto, o antagonismo serve para dar um caráter de negatividade ao que é considerado como o Outro. Porém, nem sempre os antagonismos surgem das contradições, ou até mesmo das oposições. Laclau e Mouffe argumentam que o antagonismo vem sendo estudado na literatura histórica e sociológica. Partindo do marxismo até as distintas interpretações das diversas formas de "teoria do conflito", tentando explicar as razões que levam a surgir os antagonismos na sociedade (Ernesto LACLAU \& Chantal MOUFFE, 1987, p. 209). 
Segundo a autora e o autor, qualquer identidade no âmbito social é resultado de uma articulação discursiva. Laclau e Mouffe aceitam a infinitude do social, o fato de que todo o sistema estrutural é limitado está sempre rodeado por um excesso de sentido, o social deve ser identificado como um jogo infinito das diferenças (Ernesto LACLAU, 1993, p.104). Os autores tratam a categoria de antagonismo na sociedade de uma forma especial, pois ela é importante na sua reformulação do novo conceito de hegemonia. Nesse aspecto, a teoria argumenta que uma contradição necessariamente não representa uma relação antagônica, quando se estabelece essa relação à presença de uma identidade plena, vai se tornando impossível.

O antagonismo, segundo Laclau, tem essa capacidade de estabelecer os limites de toda objetividade (Ernesto LACLAU, 1993, p.215) e isso acaba valendo para qualquer identidade. Sobre essa relação antagônica, a presença do Outro ganha ainda maior ênfase. Esse Outro, que está situado do outro lado da fronteira antagônica, adquire o aspecto de negatividade, nesse caso é identificado como o adversário. A demarcação acaba criando duas formas de identidade, esses diferentes grupos situados em lados opostos estabelecem uma relação de equivalência em cada polo. A ligação estabelecida é o que os autores chamam de cadeia de equivalências.

Com esse aporte sobre as relações antagônicas, surge a ideia desenvolvida de fronteiras no espaço discursivo. Percebe-se um adversário em relação ao qual se traça uma fronteira, um limite que cria duas grandes formas de identificação, cria um nós, do lado de cá, e cria um eles, do lado de lá (Joanildo BURITY, 2008, p.45).

As fronteiras são instáveis, revelam ambiguidade. Para compreender melhor isso, Laclau e Mouffe estabelecem as lógicas da equivalência e da diferença. A lógica da equivalência é a lógica de simplificação do espaço político, a lógica da diferença é uma lógica de expansão e complexização do mesmo (Ernesto LACLAU \& Chantal MOUFFE, 1987, p.223).

\section{CONEXÕES ENTRE RELIGIÃO E POLÍTICA}

É cada vez mais notório o envolvimento religioso na política institucional brasileira. Essa aproximação, como não poderia ser diferente, 
promove impactos no campo político, sobretudo no que concerne às discussões nos espaços públicos sobre os direitos humanos. Com o objetivo de reivindicar o lugar da religião no campo político, o avanço religioso alterou as relações em torno da laicidade do Estado e o caráter secularizante identificado nas discussões políticas nos seus diversos espaços, sejam elas originadas no Executivo, no Legislativo ou no Judiciário. Religiosas/os buscam, por meio da participação no espaço público, ampliar a influência em torno das discussões que mencionam valores que também são discutidos no âmago das instituições religiosas.

O envolvimento das/os evangélicas/os na política ganhou notoriedade nos estudos acadêmicos nas últimas décadas. Acompanhando o crescimento das igrejas evangélicas no Brasil, sobretudo as neopentecostais, o quadro atual de pesquisas voltadas para esse tema evidenciou um aumento significativo, principalmente nas análises direcionadas para a compreensão das mudanças que ocorreram em torno da inserção religiosa na esfera política, onde as/os evangélicas/os passaram a adquirir maior visibilidade em outros espaços públicos, saindo da esfera do privado. Fé e política, em algumas circunstâncias, tornam-se sinônimos.

Uma das razões utilizadas por esse grupo religioso para justificar a atuação na política, sobretudo pelos neopentecostais, é a preocupação em dar respostas concretas para as demandas do seu público. Nesta seção, serão exploradas algumas premissas teóricas utilizadas para a compreensão sociológica da religião, assim como, os fenômenos sociais provenientes dessa dimensão de estudo, como o fundamentalismo, a intolerância religiosa e as questões relacionadas ao caráter de laicidade do Estado.

No campo da sociologia da religião, José Casanova desenvolve estudos voltados para a compreensão dos novos movimentos religiosos em tempos de globalização, preocupado com questões que envolvem o transnacionalismo e o pluralismo religioso, fenômenos que conduzem a desterritorialização das religiões. A respeito da relação entre religião e política submete à análise sociológica o crescimento das religiões protestantes evangélicas, tomando como exemplo os Estados Unidos. Para tanto, o autor elenca três tipos de desestabelecimento, procurando compreender as implicações e as consequências por meio de uma 
inesperada entrada de religiões fundamentalistas na esfera pública na sociedade moderna (José CASANOVA, 1994, p.155). O primeiro desestabelecimento - A Secularização do Estado - fala acerca da separação do Estado das instituições eclesiais e da dissociação dos cidadãos oriundos de comunidades políticas de qualquer comunidade religiosa. Porém, para o autor, a secularização do Estado não trouxe em sua esteira o declínio ou a privatização da religião. Ao contrário, como é amplamente reconhecida hoje, a proteção constitucional do livre exercício da religião cria um quadro estrutural para a emergência de uma expansão sem precedentes daquilo que Martin Marty ${ }^{4}$ chama a colcha de retalhos do protestantismo denominacionalista (José CASANOVA, 1994, p.135).

O segundo desestabelecimento - A Secularização da Vida e da Mente e a Primeira Mobilização do Fundamentalismo Protestante - procura compreender os "resultados advindos da secularização no ensino superior americano e a perda de hegemonia cultural protestante sobre a esfera pública da sociedade civil americana" (José CASANOVA, 1994, p. 137). A Guerra Civil nos Estados Unidos representa o marco inicial desse processo. Para Casanova, o desestabelecimento da ética protestante provocou a secularização da moral pública e a emergência de um sistema pluralista de regras e formas de vida (José CASANOVA, 1994, p.137).

O terceiro desestabelecimento - A Secularização do Mundo da Vida e a Segunda Mobilização do Fundamentalismo Protestante - assevera que no renascimento político do fundamentalismo protestante:

(...) pode-se encontrar quatro posturas diferentes: uma reação defensiva para proteger o mundo da vida dos fundamentalistas da invasão de fora, uma ofensiva pró-ativa para restaurar o modo de vida americano, um impulso teocrático contrarrevolucionário de impor a moralidade bíblica sobre a nação e uma participação proativa nos assuntos públicos da nação. Em momentos diferentes, em diferentes setores, e em diferentes fases do movimento de qualquer uma das posturas, pode-se tomar ascendência (José CASANOVA, 1994, p. 157).

Com relação à opção desses religiosos por legendas de direita e a consequente inserção na política, Casanova argumenta que o fenômeno

\footnotetext{
Autor luterano norte-americano que possui extensa bibliografia sobre religião nos Estados Unidos.
} 
da religião no espaço público em países como Brasil, Polônia, Espanha e EUA, representa uma tendência para a desprivatização da religião, que é o processo pelo qual a religião abandona seu lugar atribuído à esfera privada e entra na indiferenciada esfera pública da sociedade civil (José CASANOVA, 1994).

Outro cientista social que desenvolve estudos sobre essa temática é David Lehmann. Seus últimos trabalhos são voltados para a compreensão dos novos movimentos religiosos carismáticos, o neopentecostalismo, o fundamentalismo islâmico e o judaísmo ortodoxo, situações que ele passou a chamar de renascimento fundamentalista no mundo. Seus estudos sobre as novas formas de valorização da religião buscam compreender os diversos tipos de fundamentalismo em nível global, não na forma de organizações fechadas, na modalidade de seitas ou qualquer tipo de agrupamento religioso sectário, avesso para/com tudo que está ao seu entorno, mas sim como organizações, cientes de tudo que ocorre no mundo, entendendo que a sua presença no mundo transcende as fronteiras estabelecidas no espaço linguístico e político. O despertar dessa consciência representa uma característica fundamental nesse projeto de pertencimento ao mundo moderno. Lehmann não procura adequar os movimentos religiosos já mencionados dentro da sua definição de fundamentalismo. Seu estudo quer compreender se esses movimentos apresentam características comuns, que possam ser utilizadas para constatar a existência de uma forma religiosa capaz de atravessar as fronteiras confessionais, e que suas particularidades são provenientes de seus atos distintos de inserção, de interpretação, dos processos contemporâneos de globalização cultural e econômica (David LEHMANN, 2000, p.82). A respeito da utilização do termo fundamentalismo, Lehmann considera:

(...) as formas carismáticas, pentecostais ou evangélicas do cristianismo, ao judaísmo ultraortodoxo e ao fundamentalismo islâmico. Não se trata de uma definição analítica, e difere das definições tradicionais porque, no que se refere ao cristianismo, tem sido habitual que os estudiosos diferenciaram nitidamente entre, por um lado, as seitas que insistem na absoluta infalibilidade do texto bíblico e, por outro, os pentecostais, que dão prioridade aos dons do Espírito. No entanto, na atualidade, dita diferença é mais de grau do que de 
espécie, pois pentecostais e evangélicos invocam rotineiramente a Bíblia como um texto infalível e, quando se compara entre igrejas e movimentos, se vê que as questões doutrinais tem pouco significado (David LEHMANN, 2000, p. 94-95).

Lehmann também observa que o envolvimento dos evangélicos na política não representa um problema para a laicidade, porque eles não estabelecem tipos de prerrogativas como aquelas exigidas pela Igreja Católica em alguns países da América Latina, no passado.

A literatura sociológica especializada almeja compreender a emergência desses novos segmentos religiosos, fenômeno que vem ocasionando uma fragmentação dessas alternativas religiosas por meio da eclosão de grupos capazes de romper as fronteiras internacionais. Isso ocorre no caso do neopentecostalismo brasileiro, ocasionando aquilo que é apontado por Patrícia Birman como consequência do pluralismo, onde o religioso deixa o campo institucional e penetra em outros espaços que são menos delimitados em suas fronteiras, produzindo não apenas novas alternativas para os sujeitos, como também novos procedimentos referentes a essas escolhas (Patricia BIRMAN, 2001, p.61). A seção seguinte apresentará os detalhes da chegada do deputado pastor Marco Feliciano (PSC-SP) à Comissão de Direitos Humanos e Minorias (CDHM) durante a 54 . Legislatura da Câmara dos Deputados.

\section{POLÊMICAS ENVOLVENDO MARCO ANTÔNIO FELICIANO}

Feliciano foi eleito, em 2010, para deputado federal pela coligação Humanista Cristão (PSC/PHS) com 211.855 votos, ${ }^{5}$ superando bastante a sua expectativa de 90 mil votos no Estado de São Paulo, e despontando como $012^{\circ}$. candidato mais votado entre os 70 eleitos na região. Membro de primeira hora da Frente Parlamentar Evangélica, Feliciano iniciou o seu mandato na $53^{\text {a }}$. Legislatura, apresentando questões de natureza religiosa na maioria de suas proposições.

No seu primeiro mandato, ${ }^{6}$ Feliciano esteve envolvido em torno de

Disponível em: < http://www.tse.jus.br/hotSites/estatistica2010/Est_resultados/resultado_eleicao. html >. Acesso em: 14 mar. 2016.

6 Reeleito em 2014, Feliciano já está no seu segundo mandato na Câmara dos Deputados (2015-2019). 
assuntos polêmicos que ocorreram fora da Câmara, mas que também ganharam repercussão no âmbito político. As questões envolvem conteúdos de cunho racista, machista e atitudes homofóbicas, que foram amplamente divulgados nos canais de comunicação do parlamentar, entrevistas e também em vídeos realizados durante suas pregações.

A respeito do episódio da sua declaração racista, no dia 31 de março de 2011, Feliciano decidiu postar na sua conta do Twitter a seguinte mensagem: "Africanos descendem de ancestral amaldiçoado por Noé. Isso é fato" (Revista Época, 2011). Em seguida, surgiram diversas manifestações contra o posicionamento de Feliciano, algumas alegando inclusive que o pastor já afirmara em outras ocasiões que os negros africanos sofrem com calamidades, pestes, fome e pobreza por descenderem de um ancestral amaldiçoado, identificado como um personagem que aparece na Bíblia, o neto de Noé. Em entrevista para a Revista Época em março de 2011,7 Feliciano justificou o seu comentário declarando que esta era uma indagação de natureza bíblica, em que o mesmo utilizou a sua conta para colocar uma pergunta para os seus alunos sobre o tema. Tentando se defender das acusações de racismo, Feliciano disse que a sua intenção não era atacar os negros, mas sim abordar que os povos africanos são amaldiçoados por possuírem uma religião diferente da cristã, ou seja, o pastor envolve-se novamente com argumentações polêmicas por meio da sua atitude que expressa intolerância religiosa.

A respeito da sua postura machista, homofóbica e antifeminista, Feliciano argumentou em entrevista cedida em 2012 (Christina VITAL DA CUNHA; Paulo Victor Leite LOPES, 2012, p. 155), diante da indagação relacionada à igualdade de direitos entre homens e mulheres, que essa igualdade poderia contribuir para a formação de uma nova tendência que colocaria sob risco a família tradicional, onde mulheres optariam por não terem filhos, afetando, dessa forma, a reprodução da espécie humana.

As feministas lutam pelo direito delas, o que é legítimo, o que a democracia permite, mas o que vem por trás de tudo isso, de maneira

Deputado Marco Feliciano: “Não aceito as atitudes homossexuais em espaço público”. Disponível em: <http://revistaepoca.globo.com/Revista/Epoca/o,,EMI222649-15223,00. $\underline{\text { html }}>$. Acesso em: 3 fev. 2016. 
subliminar, é o que me assusta, porque quando você estimula uma mulher ter os mesmos direitos do homem, ela querendo trabalhar, a sua parcela como ser mãe começa a ficar anulada, e pra que ela não seja mãe, só há uma maneira que se conhece: ou ela não se casa, ou mantém um casamento, um relacionamento com uma pessoa do mesmo sexo, e que vão gozar dos prazeres de uma união e não vão ter filhos. Eu vejo de uma maneira sutil atingir a família; quando você estimula as pessoas a liberarem os seus instintos e conviverem com pessoas do mesmo sexo, você destrói a família (Christina VITAL DA CUNHA; Paulo Victor Leite LOPES, 2012, p. 155).

Por fim, as declarações homofóbicas de Feliciano durante o $30^{\circ}$. Congresso de Gideões Missionários da Última Hora, ${ }^{8}$ em 2012, constituíram mais um momento em que o pastor esteve envolvido em controvérsias. Durante a sua pregação no evento, divulgada em vídeo na página do Congresso, Feliciano argumentou que "A AIDS é uma doença gay. A AIDS é uma doença que veio desse povo, mas se você falar vai colocar eles numa situação constrangedora, não vão conseguir verba". ${ }^{9}$ Dessa forma, Feliciano utilizou as suas declarações e atitudes negativas em relação aos homossexuais, para convocar a mobilização dos fiéis contra o que ele considera o ativismo gay, que serve, segundo o pastor, somente aos "desígnios de Satanás".

Em virtude dos seus comentários racistas e homofóbicos, foi movido em janeiro de 2013 um processo no Supremo Tribunal Federal, de autoria do Ministério Público Federal, contra Marco Feliciano, o Inquérito 3.590. A acusação ocorreu diante das manifestações de Feliciano, já citadas, na sua conta no Twitter, por possuírem natureza discriminatória com negros e homossexuais. De acordo com a denúncia, o deputado teria praticado o delito previsto no artigo 20, da Lei $7.716 / 1989$, que descreve os crimes resultantes de preconceito de raça ou de cor. Todavia, no dia 12 de agosto de 2014, a denúncia foi rejeitada por unanimidade no STF.

$8030^{\circ}$. Congresso ocorreu entre abril e maio de 2012 em Santa Catarina. O tema dessa edição era "Gideões: Unidos há três décadas na evangelização do mundo". O evento acontece todos os anos em Camboriú (SC), e reúne pastores e fiéis do Brasil e do exterior. Fonte: http://www.gideoes.com.br/congresso-dos-gideoes-2012.

9 Disponível em: < http://www.gideoes.com.br/tv-gideoes/video/604 >. Acesso em: 15 fev. 2016. 
3.1 A entrada na Comissão de Direitos Humanos e Minorias (CDHM)

Feliciano já exercia a função de membro suplente da CDHM, através da vaga do PP, desde o início de 2012, porém, os episódios relacionados à chegada de Feliciano à comissão começaram em fevereiro de 2013, mais precisamente quando lideranças partidárias definiriam em reunião as legendas que iriam dirigir as 21 comissões permanentes, dividindo estas entre as maiores bancadas na Câmara dos Deputados, de acordo com os critérios da proporcionalidade baseada no tamanho das mesmas. Nessa ocasião, o PT, que com o PMDB tinha a maior bancada, optou por abrir mão da CDHM que, historicamente, desde a sua fundação, mantinha vínculos para assumir a Comissão de Seguridade Social e Família, ${ }^{10}$ assim, o espaço aberto pelo PT, visto que os partidos possuem a liberdade para trocar de comissões, contribuiu decisivamente para a chegada do PSC à presidência da CDHM.

No dia 5 de março de 2013, o líder do partido na Câmara, deputado André Moura (PSC-SE), anunciou o nome de Marco Feliciano como presidente da $\mathrm{CDHM}$, obedecendo aos critérios de proporcionalidade já mencionados. Diante dos protestos que surgiram com a nomeação de Feliciano para a CDHM dentro e fora da Câmara, que resultaram inclusive na criação de um abaixo-assinado com mais de 50 mil assinaturas contra a posse de Feliciano, o líder do PSC ponderou que isso não surtiria efeito em uma eventual rejeição do nome do pastor na CDHM, conforme demonstra a seguinte afirmação do deputado:

Eu não creio que o nome do pastor seja rejeitado, mesmo porque esta Casa tem demonstrado respeito a todos os outros procedimentos. Portanto, há de se respeitar decisões da liderança. Eu não tenho dúvida de que será da mesma maneira na escolha agora do PSC. Dep. André Moura, PSC-SE (CÂMARA NOTÍCIAS. PSC indica Pastor Feliciano para presidência da Comissão de Direitos Humanos, ${ }^{11}$ 05/03/2013).

10 O PT também assumiu a Comissão de Constituição e Justiça e de Cidadania e a Comissão de Relações Exteriores e de Defesa Nacional. Disponível em: < http://www2. camara.leg.br/camaranoticias/noticias/POLITICA/436443-LIDERES-DEFINEM-PARTIDOS-QUE-VAO-COMANDAR-COMISSOES-PERMANENTES.html >. Acesso em: 11 jul. 2016.

1 Disponível em: http://www2.camara.leg.br/camaranoticias/noticias/DIREITOS-HUMANOS/436849-PSC-INDICA-PASTOR-FELICIANO-PARA-PRESIDENCIA-DA-COMISSAO-DE-DIREITOS-HUMANOS.html. Acesso em: 30 jul. 2016. 
Antes da posse ocorreram diversas tentativas de eleição durante as sessões na $\mathrm{CDHM}$, sempre interrompidas por ocasião dos protestos de manifestantes contrários e favoráveis ao nome de Feliciano na comissão. Diante das acusações de racismo e homofobia, Feliciano alegou que não colocaria obstáculos contra o que já estava sendo discutido na comissão, incluindo as pautas do movimento LGBT, no entanto, o parlamentar admitiu que a comissão deveria dar prioridade para outros temas, como questões voltadas para os povos indígenas. Nas seções seguintes deste artigo serão exibidos os fatos que comprovam que Feliciano impôs, sim, obstáculos para as discussões das pautas LGBT, sendo que, na maioria das ocasiões, essas pautas foram eliminadas das discussões durante a sua presidência, ao contrário do que aconteceu com as questões relacionadas aos povos indígenas, que garantiram presença constante na CDHM. Feliciano antes da posse ponderou que a CDHM não estava resumida apenas ao movimento LGBT e, ainda acerca das acusações, utilizou o seguinte subterfúgio: “Eu não tenho, repito aqui, nem nunca tive origem de racista. Nunca tive antes, nunca terei depois. A forma de provar que eu não sou racista serão as ações que vão ser empregadas na Comissão de Direitos Humanos" (CÂMARA NOTÍCIAS. PSC indica Pastor Feliciano para presidência da Comissão de Direitos Humanos, ${ }^{12}$ 05/03/2013). Para o parlamentar, a CDHM deveria dar atenção para outras áreas, como a já citada questão indígena, e os direitos dos quilombolas, assuntos que, de acordo com Feliciano, há muito tempo não são debatidos na comissão, devido ao fato de que a mesma estaria concentrando o trabalho em algumas questões e esquecendo outras. Segundo o deputado, são as "outras minorias" que interessam.

A primeira tentativa de eleição de Feliciano na CDHM ocorreu no dia 6 de março de 2013. Diante de muitas manifestações na plateia, intervenções de parlamentares e tumulto no plenário, o presidente da CDHM naquela ocasião, deputado Domingos Dutra (PT-MA), decidiu encerrar a sessão, sem realizar a escolha da nova presidência.

12 Disponível em: http://www2.camara.leg.br/camaranoticias/noticias/DIREITOS-HUMANOS/436849-PSC-INDICA-PASTOR-FELICIANO-PARA-PRESIDENCIA-DA-COMISSAO-DE-DIREITOS-HUMANOS.html. Acesso em: 30 jul. 2016. 
A FPE reagiu, diante das circunstâncias, e pediu para o presidente da Câmara, deputado Henrique Alves (PMDB-RN), a proteção para garantir o processo de escolha do novo presidente da CDHM. Na ocasião, o deputado André Moura (PSC-SE) solicitou para que a reunião fosse restrita somente a deputadas/os e assessoras/es. Mesmo com as manifestações de defensoras/es dos direitos humanos, e dos inúmeros pedidos para que o PSC indicasse outro nome, o partido resolveu manter Feliciano como presidente e o nome da deputada Antônia Lucia (PSC-AC) como vice. Sobre esses pedidos, cabe destacar o realizado por diversos pastores, pastoras, líderes religiosos de inúmeras igrejas evangélicas do Brasil, que fizeram, por meio de uma carta aberta, um apelo para que houvesse a indicação de outro parlamentar para a presidência, em virtude dos comentários de Feliciano sobre os negros e os homossexuais. A carta foi assinada por metodistas, luteranos, batistas, presbiterianos, e até mesmo por membros da Igreja Assembleia de Deus. Alegavam que a carta estava de acordo com outras petições oriundas de diversos setores, como a OAB e os movimentos sociais que atuam na defesa de minorias.

No entanto, o setor favorável à posse de Feliciano também se manifestou. A Convenção Geral das Assembleias de Deus no Brasil (CGADB), através de convenção realizada em Brasília em abril de 2013, que reuniu aproximadamente 24 mil pastores, decidiu aprovar uma moção de apoio pela permanência de Feliciano na CDHM. Por unanimidade, na Assembleia Geral Ordinária, pastoras/es aprovaram em votação simbólica o apoio ao deputado. Feliciano agradeceu e informou que "nunca houve uma comissão com tanta oração. Os pastores estão orando pela minha vida e pela comissão. Venceremos esta batalha. Quero agradecer essa moção" (PORTAL O ASSEMBLEIANO,13 10/04/2013, grifos do autor).

No dia 7 de março, Feliciano foi eleito presidente da Comissão de Direitos Humanos e Minorias. A reunião ocorreu sob protestos de alguns parlamentares do PT, PSB e PSOL, que em seguida se retiraram da eleição. ${ }^{14}$ Feliciano foi escolhido com 11 votos de 19 possíveis no to-

13 Disponível em: http://www.oassembleiano.com/2013/04/cgadb-aprova-mocao-de-apoio-ao-pr-marco.html. Acesso em: 10 abr. 2016.

14 Retiraram-se da sessão os seguintes deputados: Domingos Dutra (PT-MA), Erika Kokay (PT-DF), Padre Ton (PT-RD), Jean Wyllys (PSOL-RJ), Luiza Erundina (PSB-SP), Luiz Couto (PT-PB) e Janete Pietá (PT-SP). 
tal, sendo registrado apenas um voto em branco. Manifestantes foram impedidos de entrar na sessão, conforme a decisão do presidente da Câmara, Henrique Alves. Após a renúncia de Domingos Dutra da presidência, a CDHM passou a ser presidida provisoriamente pelo deputado evangélico Costa Ferreira (PSC-MA), que coordenou a reunião até o momento da posse de Feliciano.

A posição da FPE foi de total apoio ao parlamentar. Em nome da organização, o deputado e presidente da frente, João Campos (PSDB-GO), advertiu que a eleição de Feliciano na CDHM “obedeceu aos dois princípios principais: ao da legalidade, porque observou-se todo o rito regimental da Casa para aquela eleição; e obedeceu ao princípio da legitimidade, porque o Deputado teve a maioria absoluta dos votos" (Diário Da Câmara Dos Deputados, 2013, p. 07873). A eleição com pouco quórum em um curto espaço de tempo tratou-se de um estratagema empregado pelos deputados e deputadas da FPE e os demais favoráveis ao nome de Feliciano.

Entretanto, o parlamentar evangélico esteve envolvido em nova polêmica ainda no início dos trabalhos na CDHM. Durante um culto em um ginásio na cidade de Passo, Minas Gerais, Feliciano afirmou que a comissão era "dominada por Satanás" antes da sua chegada. No momento do culto, ocorria um protesto contra o seu nome na CDHM, do lado de fora do ginásio. Ao fazer comentários sobre os manifestantes, Feliciano declarou: "Essa manifestação toda se dá porque, pela primeira vez na história desse Brasil, um pastor cheio de Espírito Santo conquistou o espaço que até ontem era dominado por Satanás". ${ }^{15} \mathrm{~A}$ declaração de Feliciano surtiu efeito, inclusive dentro do próprio PSC. O líder do partido na Câmara, Deputado André Moura, afirmou que as declarações de Feliciano no culto foram infelizes e que precisavam ser investigadas pelos membros da Mesa Diretora da Casa. Moura asseverou que as pregações do pastor causaram constrangimento para os membros do PSC, e que essas questões deveriam ser analisadas e resolvidas pela Executiva Nacional do partido. Diante das reações dos deputados e

Disponível em: http://www1.folha.uol.com.br/poder/2013/04/1255290-feliciano-diz-que-comissao-era-dominada-por-satanas-antes-de-sua-chegada.shtml Acesso em: 3 ago. 2016. 
deputadas, inclusive com as ameaças de abandono da vice-presidência da CDHM, deputada Antônia Lúcia (PSC-AC), Feliciano pediu desculpas e afirmou que a expressão Satanás se referia aos adversários e não aos colegas da comissão. ${ }^{16}$

\subsection{A trama dos acontecimentos na CDHM}

Para entender como ocorreram os embates na CDHM antes da posse de Marco Feliciano, é necessário descrever os fatos que antecederam no processo de escolha no interior da comissão. A reunião de instalação $\mathrm{N}^{\circ}$. 0060/13 que aconteceu no dia 6 de março representou um momento sui generis para compreender esses episódios. Nesse dia, ocorreram discussões calorosas entre, de um lado, os parlamentares evangélicos e outros membros da comissão favoráveis à permanência de Feliciano, de outro, os parlamentares contrários à posse.

A conturbada reunião, ainda presidida pelo deputado Domingos Dutra (PT-MA), foi aberta após a verificação do número regimental. Dutra realizou a leitura do Regimento Interno sobre as eleições nas Comissões, e os requisitos que devem ser observados. Após a citação de Feliciano como candidato único, outros parlamentares também manifestaram o interesse em se candidatar, como foi o caso da deputada evangélica Liliam Sá (PR-RJ). Seu pedido foi negado, visto que, para se candidatar, o parlamentar precisava ser do mesmo partido, neste caso o PSC. Alguns parlamentares, em virtude das já anunciadas polêmicas em torno do nome de Feliciano, sugeriram que o PSC indicasse como presidente a deputada Antônia Lúcia (PSC-AC), alegando inclusive questões de ordem religiosa, advertindo que a deputada também era evangélica, assim como o pretendido candidato. Antônia Lúcia rejeitou a possível candidatura, admitindo que a escolha deveria ser do PSC.

As deputadas e os deputados do PT demarcaram oposição ao nome de Feliciano. A deputada Erika Kokay (PT-DF) defendeu que a candidatura de Feliciano é contrária ao que é endossado na CDHM, representando um atentado aos direitos humanos e ao Regimento Interno da Casa. Em

16 Disponível em: http://www1.folha.uol.com.br/poder/2013/04/1255961-lider-do-psc-defende-que-camara-analise-declaracao-de-feliciano-sobre-satanas.shtml. Acesso em: 3 ago. 2016. 
seguida, Jean Wyllys (PSOL-RJ) questionou sobre o procedimento de eleição do deputado, sugerindo os votos em branco para opor-se à candidatura. Ivan Valente (PSOL-SP) afirmou durante a sessão que a CDHM precisava ser dirigida por um deputado que representasse a tolerância e a democracia, justificando que sua oposição ao deputado Feliciano não era pessoal, mas que o problema era político. Em seguida, o deputado André Moura (PSC-SE) asseverou que Feliciano possuía os seus pontos de vista, e que não deveria ocorrer qualquer tipo de pré-julgamento do seu mandato frente aos trabalhos da CDHM. Chico Alencar (PSOL-RJ) ponderou acerca das colocações da deputada Erika Kokay, e sugeriu que o processo de escolha deveria ser suspenso, devido aos comentários racistas e homofóbicos do candidato. Para Alencar, o impasse poderia ser superado por meio da indicação da deputada Antônia Lúcia para a presidência. Henrique Afonso (PV-AC) conduziu para o debate justificações de natureza religiosa. Declarou que era preciso defender a religião, e que apesar de o Estado ser laico, o Brasil representava uma nação cristã. Afirmou ainda que o objetivo daqueles que são contrários ao nome de Feliciano, era tachar os evangélicos de racistas. Sua fala foi encerrada defendendo o direito do PSC de indicar o irmão Marco Feliciano. Nilmário Miranda (PT-MG) comentou que a CDHM sempre foi o lugar de respeito à diversidade religiosa, e conclamou o deputado Feliciano para manifestar na comissão suas recentes declarações nas redes sociais. No final da sessão, Jean Wyllys convocou os demais colegas, aqueles que ele considerava comprometidos com os direitos humanos, para não votar, sugerindo para que todos e todas se retirassem da reunião. Por fim, o presidente Domingos Dutra advertiu que iria procurar o presidente da Casa e os Líderes dos partidos para discutir a questão, excluindo-se da responsabilidade de conduzir uma eleição naquelas circunstâncias. Após manifestações na plateia, a sessão da CDHM foi encerrada sem eleger o seu presidente. A eleição de Feliciano ocorreu somente no dia seguinte, sem a presença de movimentos organizados, após a renúncia de Domingos Dutra do cargo de presidente e a consequente saída das/ os deputadas/os contrários ao nome do pastor. 


\section{PROPOSIÇÕES APRESENTADAS NA CDHM DURANTE A PRESIDÊN- CIA DE FELICIANO}

O período em que Feliciano esteve à frente da CDHM foi marcado por uma forte oposição de parlamentares contrários ao seu mandato, por protestos de organizações que atuam na defesa dos direitos humanos e também de baixa produção legislativa. ${ }^{17} \mathrm{~A}$ maioria das proposições apresentadas nesse período foi arquivada. Nesta seção, serão exibidos os dados relativos aos conteúdos dessas proposições, os seus autores e autoras, a data de apresentação, a situação atual, e também, no caso daqueles/as deputados/as que são vinculados/as à Frente Parlamentar Evangélica (FPE), ${ }^{18}$ as filiações religiosas mais ativas dentro da comissão.

Antes de ser empossado, Feliciano advertiu que o seu mandato frente ao órgão daria prioridade para outras questões, que no seu entender, não estavam sendo tratadas com a devida atenção na CDHM. É o caso da questão indígena e os direitos dos quilombolas. ${ }^{19}$ De fato, ao longo da gestão, muitas matérias foram apresentadas por parlamentares evangélicos e não evangélicos mencionando os temas já citados.

Contudo, outros assuntos também foram explorados no interior dessas proposições apresentadas, como temas relativos ao meio ambiente, segurança, saúde, criminalidade e exploração sexual. Todas

17 O retrocesso na produção legislativa foi identificado em comparação com os anos anteriores. Fonte: http://oglobo.globo.com/brasil/com-feliciano-comissao-de-direitos-humanos-teve-retrocesso-11130426. Acesso em: 3 ago. 2016.

18 Os deputados evangélicos constituem a maioria dos autores das proposições identificadas.

19 O interesse dos parlamentares evangélicos pelos indígenas e quilombolas na CDHM pode ser justificado pelo crescente processo de evangelização que está sendo empregado pelas igrejas evangélicas com esses povos. Segundo os dados do IBGE do Censo de 2010, ocorreu um aumento de índios evangélicos nos últimos dez anos, $42 \%$. Esse aumento segue a tendência geral da população no Brasil (FOLHA DE SÃO PAULO. Índios evangélicos aumentam 42\% em 10 anos e já são 210 mil - 22/07/2012, p.01. Disponível em: http://www1.folha.uol.com.br/poder/2012/07/1123927-indios-evangelicos-aumentam-42-em-10-anos-e-ja-sao-210-mil.shtml. Acesso em: 15 fev. 2016). Nas comunidades quilombolas a presença evangélica também é notória, contudo, o trânsito religioso entre os quilombolas e o crescente sincretismo não significa uma maior aceitação dos membros das igrejas evangélicas com as religiões de matriz africana locais, pois em alguns casos essa relação ocorre em um ambiente hostil por parte dos evangélicos com as práticas dos quilombolas adeptos das religiões afro-brasileiras (Julia Miranda Soares CAMPOS, 2012). 
essas temáticas compuseram a maioria das proposições que foram submetidas à apreciação nos trabalhos da comissão. Majoritariamente, essas matérias sujeitas à deliberação foram exibidas na forma de requerimento. Embora em menor quantidade, também foram identificados outros modelos de proposição, como: Projeto de Decreto Legislativo, Proposta de Fiscalização e Controle e Projeto de Lei. Como os membros da FPE obtiveram o domínio da CDHM, era de se esperar também o predomínio deles como autores de proposições apresentadas durante a presidência de Feliciano.

Os parlamentares evangélicos apresentaram 146 proposições (88\%), e os não evangélicos 20 proposições (12\%). É importante recordar que muitos desses parlamentares não evangélicos, que permaneceram na comissão, eram correligionários de Marco Feliciano, e também das ideias defendidas e submetidas pelos membros da FPE para a apreciação na CDHM, é o caso dos deputados Jair Bolsonaro (PP-RJ), Severino Ninho (PSB-PE), Simplício Araújo (PPS-MA) e da deputada Keiko Ota (PSB-SP).

Com relação à filiação religiosa dos membros da CDHM naquele período, entre os parlamentares evangélicos que mais apresentaram proposições, destacam-se os membros da Assembleia de Deus, 96 proposições foram elaboradas pelos membros dessa igreja, uma grande diferença para a denominação religiosa que aparece na segunda colocação, a Igreja Presbiteriana, com 19 proposições apresentadas. Entre os parlamentares evangélicos da Assembleia de Deus que mais exibiram proposições, sobressaem-se os seguintes nomes: deputado Marco Feliciano (PSC-SP), com 20 proposições; deputado Marcos Rogério (PDT-RO), com 16 proposições; deputado Zequinha Marinho (PSC-PA), com 14 proposições; deputada Antônia Lúcia (PSC-AC), com 11 proposições, e o deputado Pastor Eurico (PSC-PE) com 11 proposições. De outras denominações religiosas os mais destacados foram os seguintes nomes: da igreja Presbiteriana o deputado Henrique Afonso (PV-AC), com 12 proposições; da Igreja Brasil para Cristo o deputado Roberto de Lucena (PV-SP) também com 12 proposições, e da Igreja Batista o deputado Walter Tosta (PSD-MG), com 10 proposições.

As informações denotam o predomínio dos membros da Assembleia de Deus na CDHM, que souberam utilizar estrategicamente a comissão 
para promover, em algumas circunstâncias, suas pautas motivadas por valores religiosos ou por questões que também são tratadas no interior das igrejas, como a valorização da família, o combate à pornografia, tráfico e consumo de drogas e o aborto. Todavia, apesar dos esforços empreendidos pela FPE dentro da CDHM para favorecer a sua agenda política/confessional, os evangélicos não obtiveram um bom êxito em torno da tramitação das proposições na comissão. Quase todas as matérias encontram-se arquivadas.

O legado de Feliciano frente à CDHM demonstra que das 166 proposições apresentadas, 157 (95\%) foram arquivadas. As nove proposições restantes, (5\%), encontram-se em outras situações. ${ }^{20}$ Os dados demonstram a ineficácia e o fracasso da sua gestão em comparação com os anos anteriores da mesma legislatura. Comparando com 2011 e 2012, ocorreu uma baixa em torno da votação de requerimentos. Também ocorreram menos eventos como palestras, seminários e audiências promovidas pela CDHM durante a presidência de Feliciano, algo que não é muito comum, em virtude do hábito da comissão de realizar atividades anualmente para discutir temas relacionados aos direitos humanos. Com Feliciano, esse aspecto da CDHM foi desprezado. Ainda sobre a atuação do pastor no cargo, comparando com as gestões anteriores da CDHM durante a mesma legislatura, ou seja, a gestão de Manuela d'Ávila (PCdoB-RS), em 2011, e de Domingos Dutra (PT-MA), em 2012, Feliciano foi o menos atuante com relação à autoria de requerimentos apresentados (Magali CUNHA, 2014, p.01). ${ }^{21}$

20 Em 07/08/2017, a legenda "outras" engloba as seguintes situações: aguardando parecer; tramitando em conjunto; aguardando designação do relator; pronta para pauta e aguardando providências internas. Alguns exemplos de proposições que se encontram nessas situações: PDC 1427/2013 de autoria do deputado Vilson Covatti (PP-RS), que procura sustar a Portaria $n^{\circ}$. 388 de 2014 do Ministro de Estado da Justiça, que declara posse permanente do grupo indígena Kaigang à região Rio dos Índios no Rio Grande do Sul; PFC 149/2013 de autoria da CDHM, que propõe que a própria CDHM fique encarregada de fiscalizar os órgãos responsáveis por atender a população atingida pela contaminação de chumbo e outros metais pesados em todo o Brasil; PL 7.103/2014 de autoria da deputada Benedita da Silva (PT-RJ), cujo propósito é modificar o Estatuto da Igualdade Racial para inserir o quesito cor ou Raça nos prontuários, cadastros ou outros registros no Sistema de Informação em Saúde do SUS.

21 Disponível em: < http://www.diplomatique.org.br/artigo.php?id=1620 >. Acesso em: 7 ago. 2015. 
No seu trabalho de análise sobre as ações executadas na CDHM durante a presidência de Feliciano, Magali Cunha (2014) constata que não ocorreram avanços em relação à proposições de leis ou outras matérias, atuação na defesa dos direitos humanos, ou até mesmo por meio da fiscalização dos atos do Executivo. Segundo Magali Cunha (2014), o que ocorreu em 2013 na CDHM foi a tramitação de temas considerados questionáveis e irrelevantes. Feliciano, por exemplo, advertira que a CDHM não daria mais prioridade aos temas voltados para os direitos dos homossexuais. Trata-se de um discurso utilizado pelo parlamentar na tentativa de justificar a sua atuação contrária aos direitos desse segmento com o propósito de colocar obstáculos para as pautas LGBTs. Durante a sua presidência, Feliciano adotou manobras para barrar essas pautas, por meio da apresentação de proposições polêmicas (Cura gay) e na rejeição do Projeto de Lei 6.297/2005..$^{22}$

A seção seguinte deste trabalho será destinada à análise discursiva dos excertos que envolvem alguns desses temas, assim como os discursos que ocorreram durante as sessões legislativas da CDHM que evidenciaram o grau de antagonismo entre os correligionários de Feliciano e os parlamentares contrários à sua permanência na comissão.

\section{ANÁLISE DISCURSIVA DOS PRONUNCIAMENTOS SOBRE MARCO FELICIANO}

No espaço discursivo investigado neste artigo, três características sobre os discursos de parlamentares evangélicos que atuam na defesa de Marco Feliciano na CDHM se sobressaem: em primeiro lugar, as diversas formas utilizadas para identificar o outro, ou seja, os adversários que procuraram tolher a posse de Feliciano na CDHM; em segundo lugar, o grau de recorrência perene aos argumentos que procuram situar os evangélicos como vítimas, isto é, enquanto um segmento religioso que sofre constantemente incriminações, não somente na Câmara dos Deputados, mas em outros ambientes e em terceiro lugar a frequente

22 O Projeto de Lei de autoria de Mauricio Rands (PT-PE) pretendia incluir na situação jurídica de dependente, para fins previdenciários, o companheiro ou companheira homossexual do segurado ou segurada do INSS e o companheiro ou companheira homossexual do servidor(a) público(a) civil da União. 
justificativa de que somente com a chegada de Feliciano à CDHM é que seriam discutidos os verdadeiros direitos humanos, de acordo com os evangélicos, gerando uma confusão em torno da utilização do termo, muitas vezes sendo aplicado em torno de temas que não têm nada a ver com os direitos humanos, fato esse que contribuiu para o arquivamento de $95 \%$ das proposições apresentadas.

Além desses traços identificados durante a análise discursiva dos pronunciamentos das/os deputadas/os da FPE, outras características, em menor intensidade, também foram verificadas, por exemplo, as constantes referências aos argumentos de guerra religiosa, ou seja, de uma luta travada entre o bem e o mal na CDHM; a reiteração constante de um discurso adulador em torno do nome de Marco Feliciano, exageradamente adjetivado; e o recurso de enunciações delocutivas (Patrick CHARAUDEAU, 2013, p.178), isto é, a constante referência enquanto estratégia discursiva de uma terceira pessoa, neste caso, o desejo da maioria do povo que é cristão, para justificar a chegada de Feliciano à presidência da CDHM, isentando de responsabilidade os interlocutores pela suas afirmações, em virtude do tom assertivo e da autoridade de um discurso que representa a verdade absoluta, sem falhas, inatacável. A estratégia era calar os opositores por desqualificar qualquer argumento contrário. Essa seção estará concentrada em torno desses temas, que serão explorados a partir da análise dos discursos registrados durante o período que compreende a presidência de Feliciano.

Optou-se pela distinção entre os discursos de parlamentares evangélicos e não evangélicos, pois que havia uma superposição entre a afiliação religiosa e o apoio a Feliciano. Todavia, entre os pronunciamentos de evangélicas/os, encontram-se também fragmentos de discursos de deputadas/os que não pertencem ao segmento religioso verificado neste artigo, por exemplo, o deputado federal Jair Bolsonaro (PP-RJ), em virtude da sua aproximação ideológica com os membros da FPE em torno dos principais assuntos tratados na CDHM, e também pela sua defesa intransigente de Marco Feliciano enquanto presidente da comissão.

Entre os discursos coletados e submetidos à análise, três características podem ser identificadas. A primeira diz respeito ao uso constante da expressão de negação ou recusa "Não", verificada no discurso das/ 
os opositoras/es. Em diversas ocasiões os parlamentares contrários utilizaram orações que clarificam esse recurso, como demonstram os fragmentos a seguir:

“(...) a CDHM ñ̃o pode ser presidida (...)";

“(...) eu não estaria fazendo qualquer oposição (...)”;

“(...) não é possível que esta Casa simplesmente admita que uma pessoa que se caracterizou (...) por posturas homofóbicas ou posturas racistas possa assumir a Comissão de Direitos Humanos";

“(...) não podemos admitir que tenhamos que assistir à morte em vida desta Comissão (...)";

"Não se pode colocar para presidir uma Comissão quem já tem uma ideia preconceituosa";

"Será uma Presidência e uma Comissão, em 2014, de permanente crise, o que não ajuda este Parlamento";

"(...) a Câmara dos Deputados não pode ficar, mais uma vez, de costas para o clamor da sociedade" (grifos do autor).

Os trechos citados compõem o espaço discursivo do polo oposto e demonstram a estratégia discursiva utilizada pelas/os deputadas/os contrárias/os ao parlamentar evangélico frente à $\mathrm{CDHM}$, recorrendo constantemente à censura do nome de Feliciano, tentando desgastar a sua imagem por intermédio das atitudes de reprovação, tendo em vista os assuntos polêmicos em que Feliciano esteve envolvido.

A segunda característica está relacionada à utilização das palavras mulher e minoria, entendidas como termos que compõem o vocabulário das discussões sobre os direitos humanos. Percebe-se que entre os defensores de Feliciano a palavra mulher não é mencionada, ${ }^{23}$ diferenciando-se do que ocorre nos discursos dos deputados opositores, que

23 Apesar de serem identificadas menções sobre a violência doméstica contra as mulheres em algumas proposições apresentadas na CDHM pelos parlamentares evangélicos, foram escassas as ocasiões que os membros da FPE se preocuparam em trazer à tona esse tema. 
discutiam questões em torno das violações dos direitos das mulheres e de outros grupos, conforme apontam os fragmentos a seguir:

“(...) índices alarmantes de violência contra jovens, negros e negras, pobres, mulheres, comunidade LGBT";

"(...) a violência contra a mulher deve ser repudiada em especial”;

“(...) mais segurança às mulheres que denunciam seus agressores (...)”;

"Não é em nome de Cristo, não é em nome de Cristo que se prega o ódio às pessoas, o ódio à comunidade LGBT, o ódio às mulheres, aos negros e africanos" (grifos do autor).

O mesmo ocorre que o recurso da palavra minoria, explorada pelos deputados opositores por meio da lógica de defesa dos direitos das minorias, mas pouco mencionada pelos deputados evangélicos, ou quando citada, somente no momento em que os religiosos se autoproclamam enquanto uma minoria que é perseguida e sofre intolerância de modo a assumirem a posição de vítimas no conflito religioso no qual são aguerridos opositores de outras religiões.

A terceira característica identificada nos discursos está relacionada à utilização de enunciações elocutivas, ou seja, os ditos que são proferidos com o recurso de pronomes pessoais de primeira pessoa seguidos de advérbios, verbos nodais e qualificativos que evidenciam o envolvimento do orador e a sua opinião (Patrick CHARAUDEAU, 2013, p.174). Entre os discursos dos defensores de Feliciano, foram poucas as utilizações de enunciações elocutivas. Porém, entre os pronunciamentos dos opositores de Feliciano, foram encontrados diversos enunciados responsáveis pela manifestação de opiniões pessoais, conforme evidenciam os exemplos a seguir:

“Eu pertenço a uma minoria estigmatizada (...)";

"Eu me oponho à presença de Feliciano (...)";

"Eu tenho visto vídeos que me chocam, e não apenas aquele de fazer mercado da fé (...)"; 
"Eu acho que esta Casa tem que ouvir a voz da sociedade (...)";

"Nós, gays, lésbicas, bissexuais, travestis e transexuais, fomos perseguidos (...)";

"(...) o que nós vimos nesta Casa semana passada foi um atentado dos mais graves a uma Comissão (...)";

"(...) nós queremos uma Casa que dialogue com o povo";

"(...) ou nós tomamos uma providência em relação a isso, ou vai ficar muito difícil resgatar a confiança e o respeito do povo brasileiro";

"Ofendeu todos nós, recentemente, já no exercício do mandato (...)" (grifos do autor).

Os excertos comprovam que os opositores da candidatura de Feliciano utilizaram como estratégia discursiva o recurso das enunciações elocutivas enquadradas dentro da modalidade de rejeição, ou seja, recusando as ações do adversário. Aqui, seguindo o trabalho de Patrick Charaudeau (2013), a rejeição identificada nos discursos, invoca o que o autor entende como o etos de sério, que procura situar-se como o discurso que traz a verdade, que representa o combatente, que pretende esclarecer o povo sobre o que está acontecendo e atrai para si essa responsabilidade (Patrick CHARAUDEAU, 2013, p.175). O emprego do nós, enquanto enunciado elocutivo, também transmite uma ideia de solidariedade entre os opositores de Feliciano, uma coesão em torno das opiniões e a certeza de que estão cumprindo com os seus deveres como oposição na CDHM.

\subsection{O polo antagônico: a identificação do outro na fronteira discursiva}

Os parlamentares evangélicos não economizaram o uso de adjetivos, alguns pejorativos, para identificar os adversários que se opunham ao nome de Feliciano enquanto presidente da CDHM. Para compreender essas utilizações, será realizada a tentativa de aplicação dos conceitos de agonismo e antagonismo, examinados minuciosamente por Chantal Mouffe (2007, 2012, 2014), e também para entender a recorrência de um 
discurso baseado em preceitos morais, ou seja, que busca estabelecer o conflito religioso maniqueísta entre o bem e o mal, o último representado pelos adversários dos evangélicos na CDHM e em outros âmbitos. Esse maniqueísmo é próprio dos fundamentalistas cristãos.

Desde as primeiras discussões sobre a chegada de Feliciano na CDHM, foi possível identificar, enquanto estratégia discursiva, esse empenho empreendido para caracterizar o outro. A seguir, alguns excertos coletados nas diferentes fases da sessão plenária da Câmara que evidenciam esse método utilizado pelos evangélicos:

Ocupo esta tribuna para tentar desatar o nó dado pelo movimento LGBT, que vem fazendo campanha contra a eleição do Presidente da Comissão de Direitos Humanos e Minorias, o Deputado Pastor Marco Feliciano. Não é de hoje que se criam argumentos para denegrir a imagem de alguém. Dep. Pastor Eurico, PSB - PE (Diário da Câmara dos Deputados, 12/03/2013, Sessão: 029.3.54.O / GE).

O que se põe hoje é que uma minoria não permite que haja o debate. Simplesmente, com baderna, com algazarra, com a intenção de não permitir o debate, uma minoria quer calar os Parlamentares majoritariamente da Comissão. Dep. Arolde de Oliveira, PSD - RJ (Diário da Câmara dos Deputados, 26/03/2013, Sessão: 046.3.54.0 / OD).

Não podemos ficar reféns aqui, Sr. Presidente, de baderneiros e ativistas que querem manipular a opinião pública. $O$ pior é homens da envergadura de Deputados aqui da Casa irem na conversa dessa gente. Dep. Takayama, PSC - PR (Diário da Câmara dos Deputados, 26/03/2013, Sessão: 046.3.54.0 / OD).

Agora, o que está ocorrendo na Comissão de Direitos Humanos e Minorias não é manifestação, é anarquia, é baderna, é ofensa ao Presidente, é xingamento. Quando o Presidente vai usar a palavra, a turma de ativistas grita para Ihe abafar. Ora, não dá! Democracia não se compatibiliza com baderna." Dep. João Campos, PSDB - GO (Diário da Câmara dos Deputados, 04/04/2013, Sessão: 054.3.54.O / OD).

Nos excertos citados, é possível identificar os diversos adjetivos, alguns difamatórios, que os oponentes de Feliciano receberam, como: minoria, baderneiros, turma de ativistas. Tudo isso constitui o arcabouço 
que forma o polo antagônico situado no campo discursivo desta análise. Chantal Mouffe explica que é no domínio das identificações coletivas, aqui representadas pela FPE, que são identificadas as diferenças, criando um nós por meio da delimitação de um eles, sempre existindo:

(...) a possibilidade de que esta relação nós/eles se transforme em uma relação amigo/inimigo, quer dizer, que se converta na sede de um antagonismo. Isto se produz quando se começa a perceber o outro (...) como negação de nossa identidade e como questionamento de nossa existência' ${ }^{24}$ (Chantal MOUFFE, 2014, p. 15-16).

Percebe-se nos pronunciamentos dos parlamentares evangélicos que a presença desse outro é fundamental para a edificação dos seus discursos. A identificação de um outro é constituinte de um nós. Contudo, é uma relação amigo versus inimigo, porque ela não dá margem para um consenso, ou seja, um acordo entre os polos. O que prevalece nos discursos dos parlamentares evangélicos é a relação antagônica, visto que os mesmos não se preocupam em entender o inimigo enquanto adversário. A posse de Feliciano e os discursos na CDHM demonstraram que nem mesmo sequer ocorreram tentativas de diálogo pelos demais parlamentares evangélicos do PSC e de outros partidos. Cada iniciativa tomada pelos deputados contrários ao nome de Feliciano, em virtude do seu envolvimento em questões polêmicas, era rechaçada. A seguir, serão apresentados os discursos que compõem o polo oposto, ou seja, o outro na cadeia discursiva:

A indicação do Deputado Pastor Marco Feliciano - contra o qual não temos nada pessoal, não temos amizade nem inimizade - gerou essa polêmica. E não por declaração de nenhum Deputado. Toda a reação foi de Parlamentares e da sociedade. Repito: não foi só dos movimentos sociais. Há mais de 400 mil manifestações nas redes sociais por conta das declarações do pastor. Nós somos a favor dos evangélicos. Eu, pessoalmente, tenho três irmãs que são evangélicas. Sou amigo de vários pastores no Maranhão, como o Pastor Bel, como o Pastor Sampaio. Não é isso o que está em julgamento. Não é se é pastor, se é evangélico, se é ator. $O$ que está em discussão

24 Todas as traduções são de inteira responsabilidade do autor deste artigo. 
é a postura, é o preconceito, é o discurso do Pastor Feliciano. Por isso, não é a reação de um grupo específico, é a reação de milhares de brasileiros que não aceitam que a Comissão de Direitos Humanos seja presidida por um Deputado mais atrasado do que o Supremo. Dep. Domingos Dutra, PT - MA (Diário da Câmara dos Deputados, 12/03/2013, Sessão: 029.3.54.0 / GE).

Por isso, Sr. Presidente, o PSOL quer desta tribuna pedir e continuar pedindo. Não se trata de tirar o direito sagrado do PSC de indicar proporcionalmente, no seu partido, na Comissão que lhe foi outorgada, mas se trata de entender que a divulgação nos meios de comunicação e nos meios eletrônicos de posições intolerantes, de posições que atentam contra os direitos humanos, é incompatível com a Comissão, com os seus objetivos, com a sua história, com o avanço democrático, com a luta contra a intolerância. Dep. Ivan Valente, PSOL - SP (Diário da Câmara dos Deputados, 13/03/2013, Sessão: 030.3.54.0 / OD).

(...) também quero me associar às palavras ditas aqui pelos membros da Comissão de Direitos Humanos, ou seja, que as teses que o Pastor Marco Feliciano tem defendido e defendeu são incompatíveis com a razão de existir da Comissão de Direitos Humanos. Então, é importantíssimo que haja um bom senso neste sentido e que o PSC possa alterar o seu nome, o nome que indicou para aquela Comissão. Porque o que é pior, além dessas teses incompatíveis, é uma tentativa de mudar a agenda da Comissão de Direitos Humanos. Isso é um retrocesso estúpido à defesa das minorias, ao combate à intolerância! Dep. Márcio Macêdo, PT - SE (Diário da Câmara dos Deputados, 14/03/2013, Sessão: 031.3.54.O / OD).

Nesses fragmentos, é possível identificar claramente as tentativas empreendidas pelos parlamentares contrários ao nome de Feliciano para a presidência da CDHM, apresentando como proposta a substituição do parlamentar pelo seu partido, no caso, o PSC. Também é possível verificar que a oposição se dá em virtude das opiniões polêmicas já citadas neste artigo e não pela filiação religiosa do pastor. São discursos que apresentam um teor mais conciliatório, comparado com os discursos provenientes de parlamentares evangélicos.

O discurso evangélico, que atua na defesa de Feliciano, apesar de ser edificado em um espaço em comum com os opositores, o plená- 
rio da Câmara, não chega a constituir uma relação agônica, pois, ele não identifica o outro enquanto adversário, mas sim como inimigo. $\mathrm{O}$ demérito do opositor pelos evangélicos, no momento da elaboração de seus discursos é constante. A respeito desse aspecto do discurso, Patrick Charaudeau explica que "é na estigmatização da origem do mal que é preciso inscrever também as estratégias de desqualificação do adversário, sendo este um dos polos constitutivos do discurso político" (Patrick CHARAUDEAU, 2013, p. 92). Substituindo apenas nessa citação que a desqualificação que ocorre é do inimigo e não do adversário, o raciocínio de Patrick Charaudeau coincide perfeitamente com o que é entendido neste artigo como elemento constituinte do discurso evangélico, pois trata-se de um discurso que identifica o opositor como um mal, que precisa ser extirpado, basta lembrar a manifestação pública de Feliciano em um culto religioso que afirmou que a CDHM antes da sua chegada era dominada por Satanás.

\subsection{Evangélicos na condição de vítimas: a estratégia discursiva}

A coleta dos pronunciamentos também identificou que os deputados evangélicos utilizaram de forma constante o argumento de que representam um grupo perseguido, que são vítimas de ataques de outros segmentos que não aceitam a inclusão dos evangélicos na política institucional. A seguir, alguns excertos que demonstram esse recurso discursivo utilizado pelos membros da FPE no momento das discussões sobre a posse de Feliciano:

(...) uma minoria quer calar os Parlamentares majoritariamente da Comissão. Essa foi a realidade que aconteceu lá. Fora disso, é... (O microfone é desligado.). No meu entendimento, está havendo, naquela Comissão, perseguição religiosa como de resto em todo o Brasil. Dep. Arolde de Oliveira, PSD - RJ (Diário da Câmara dos Deputados, 26/03/2013, Sessão: 046.3.54.0 / OD, grifos do autor).

Nesta hora, em que precisamos unir forças, conclamo pessoas de todas as religiões para nos irmanarmos por um ideal comum em defesa da família e da vida, pois o inimigo é ardiloso. Quando nos acusam de fundamentalistas, tentam desviar o foco de suas reais intenções, que são de tentar impor seus valores onde forças não 
tão ocultas, mas ardilosas, tal qual a serpente citada na Bíblia, tentam impor uma nova nomenclatura "gênero" ao se referir ao sexo masculino ou feminino, excluindo as palavras "pai” e "mãe”. Dep. Pastor Marco Feliciano, PSC - SP (Diário da Câmara dos Deputados, 16/12/2013, Sessão: 416.3.54.O / CP).

Os fragmentos citados revelam que boa parte dos deputados evangélicos personifica o papel de vítima, afirmando que existem grupos, aqui entendidos como minorias, ativistas, que desrespeitam a orientação religiosa. No estabelecimento de um nós, ou seja, evangélicos entendidos enquanto vítimas, representantes dos verdadeiros valores da família tradicional, como está explícito no pronunciamento citado de Marco Feliciano, torna-se possível identificar o exato momento que entram nas discussões os argumentos de caráter moral, estimulando os embates entre o bem e o mal, abandonando os elementos que caracterizam as categorias políticas usuais em torno de posições antagônicas, ou seja, de disputa de projetos, entre esquerda e direita (Chantal MOUFFE, 2014, p.17).

Em decorrência do descrédito dos partidos e da extinção das fronteiras que movimentam a política, Mouffe observa que isso contribui para o surgimento de outros tipos de identidades coletivas, capazes de penetrar na política, como as religiosas, nacionalistas ou étnicas. Dessa forma, a autora verifica que:

(...) o que está acontecendo na atualidade não é o desaparecimento do político na sua dimensão adversária, mas sim algo diferente. $O$ que ocorre é que atualmente o político se expressa em um registro moral. ${ }^{25} \mathrm{Em}$ outras palavras, ainda consiste em uma discriminação nós/ eles, porém o nós/eles, em vez de ser definido mediante categorias políticas, se estabelece agora em termos morais. Em lugar de uma luta entre "esquerda e direita" nós enfrentamos uma luta entre "bem e mal" (Chantal MOUFFE, 2007, p. 12-13).

De acordo com os discursos dos parlamentares evangélicos que atuam na defesa de Feliciano, o que ocorre na verdade não é o desaparecimento da dimensão antagônica, mas sim a sua manifestação por

25 Grifos do autor. 
meio de outros caminhos, neste caso o religioso, que passa a ocupar a dimensão política no momento em que o enfrentamento democrático desaparece. Chantal Mouffe também analisa que o desenvolvimento de um discurso moralista e a consequente expansão de vários tipos de fundamentalismo religioso são algumas das consequências decorrentes do vazio da vida política, e pela ausência de formas de identificação democráticas, orientadas por valores políticos rivais (Chantal MOUFFE, 2012, p.127). O caso investigado neste artigo corrobora a tese de Chantal Mouffe, isto é, o discurso evangélico sobre Feliciano possui como característica a mobilização de argumentos moralistas, assim como o fato de que essas identidades religiosas, quando entram no jogo político, não pretendem abrir espaço para o diálogo com outros segmentos que discordam de suas teses, evidenciando, assim, um elevado grau de sectarismo em torno de suas posições, fato esse que foi evidenciado nas sessões anteriores à posse de Feliciano na CDHM, com a atitude insolente dos membros da FPE diante da recusa de qualquer tentativa de diálogo com os seus opositores.

\subsection{Direitos humanos na concepção dos parlamentares evangélicos}

Outra característica identificada nos discursos que atuaram na defesa de Feliciano, mais precisamente a partir do momento que o mesmo assumiu os trabalhos na CDHM, foi a definição dada para os direitos humanos pelos deputados evangélicos. Ou por desconhecimento do que realmente representam os direitos humanos, ou pela simples tentativa de estabelecer um contraponto à forma como os direitos são entendidos, os evangélicos conduziram para o domínio político uma concepção bem diversa do que efetivamente se entende sobre esses direitos. Os trechos citados a seguir procuram expor essa diversidade, demonstrando que os evangélicos se apresentam como segmento incumbido de uma tarefa, a de defender os verdadeiros direitos humanos.

Apesar de tantos movimentos contrários, hoje à tarde tivemos uma reunião saudável, muito boa, produtiva, oito requerimentos foram aprovados. Estamos vendo começar a andar os verdadeiros direitos humanos nesta Casa. Dep. Pastor Eurico, PSB - PE (Diário da Câmara dos Deputados, 03/04/2013, Sessão: 053.3.54.0 / OD). 
Nós entendemos, a Frente Parlamentar Evangélica, que a eleição do Deputado Marco Feliciano, mesmo havendo sobre ela divergência, que é própria do Parlamento, é um ganho para esta Casa e um ganho para a sociedade brasileira, porque a Comissão de Direitos Humanos e Minorias, a partir da eleição de S.Exa., tem a oportunidade de discutir direitos humanos em uma perspectiva mundial, sem estar subordinada a ideologias, a partidos ou a guetos ideológicos. A Comissão vai discutir agora direitos humanos em todas as suas vertentes. Isso é um ganho para esta Casa e para o Parlamento. Dep. João Campos, PSDB - GO (Diário da Câmara dos Deputados, 03/04/2013, Sessão: 053.3.54.O / OD).

No dia a dia, a defesa dos direitos humanos é feita pela Comunidade Evangélica por meio de ações e acolhimento e não apenas através de protestos, manifestações, eventos e seminários. Ela acolhe os excluídos deste País, oferece o trabalho de comunidades terapêuticas, disponibiliza abrigos para crianças e idosos e também programas de educação e saúde aos ribeirinhos. Dep. Roberto de Lucena, PV - SP (Diário da Câmara dos Deputados, 01/04/2013, Sessão: 049.3.54.O / CP).

A participação de agentes públicos que trabalham no combate e prevenção à prática do aborto em muito contribuirá para sabermos o que vem sendo feito para minimizar a prática do aborto no Brasil. Ao trazer à baila o assunto na Comissão de Direitos Humanos e Minorias, entendemos que estamos defendendo aquele que sofre a mais injusta violação aos direitos humanos: a condenação à morte sem direito à defesa, sem discussão, de maneira covarde e cruel. Dep. Henrique Afonso, PV - AC (Diário da Câmara dos Deputados, 04/06/2013, Sessão: 0661/13 / CDHM).

Os fragmentos mencionados evidenciam a preocupação dos parlamentares evangélicos em trazer à discussão o que entendem por direitos humanos. Contudo, na forma como é utilizado o termo, é possível notar uma imprecisão no emprego. Os evangélicos, como demonstra o pronunciamento do deputado pastor Eurico, entendem que existem outros tipos de direitos humanos, constituindo os verdadeiros, diferentes daqueles que estavam sendo discutidos na comissão até então. Já o pronunciamento do deputado João Campos, demonstra que, com a chegada de Feliciano, os direitos humanos passariam a ser discutidos por meio 
de uma perspectiva global, sem a influência de ideologias ou partidos, porém, o parlamentar não esclarece o que seriam todas as vertentes que os direitos humanos estariam incluídos. Talvez, essas outras vertentes aludidas pelo parlamentar sejam aquelas explicitadas pelos deputados Roberto de Lucena e Henrique Afonso, já citados respectivamente. O primeiro defende a forma como as comunidades evangélicas tratam da questão dos direitos humanos, ou seja, por intermédio de atividades filantrópicas; o segundo, abordando a questão do aborto, entende que os direitos humanos devem ser assegurados ao embrião, configurando assim em algo que não é comum no que diz respeito à discussão desses direitos. Porventura, a inovação que os evangélicos mencionam pode estar relacionada à introdução dessas discussões atípicas?

Durante os trabalhos legislativos na comissão, três temas explorados pelos parlamentares evangélicos apontam essas inovações no que diz respeito à utilização do termo direitos humanos. O primeiro assunto foi a discussão sobre a população contaminada por chumbo e outros metais no município de Santo Amaro da Purificação, na Bahia em março de 2013. A discussão do tema coincidiu com o período de protestos realizados nas cercanias da CDHM, contra a permanência de Feliciano na presidência. A proposta da CDHM a respeito do assunto ${ }^{26}$ buscava trazer soluções para os moradores da região atingida, bem como um trabalho de recuperação ambiental nas áreas degradadas pela contaminação, punindo a empresa responsável pelo lançamento de resíduos, assim como a identificação dos impactos gerados.

Trata-se de um tema que pouco tem a ver com o que é discutido na $\mathrm{CDHM}$, porque é um assunto que poderia ser discutido em outros espaços, por exemplo, na Comissão de Meio Ambiente e Desenvolvimento Sustentável - CMADS. Deputados evangélicos defendiam que o assunto não vinha sendo abordado na CDHM pelo fato de que a comissão se envolvia apenas com outros assuntos menos importantes, ou seja, as pautas particulares, e que os assuntos mais importantes estavam sendo deixados de lado, como a contaminação por chumbo.

26 Realizada por meio do Projeto de Fiscalização e Controle 149/2013, baseado no trabalho do GT Chumbo, coordenado pelo deputado evangélico Roberto de Lucena (PV-SP). 
O segundo assunto explorado pelos evangélicos na CDHM foi o Projeto de Decreto Legislativo 234/2011, de autoria do deputado evangélico João Campos, PSDB-GO. O projeto, que já se encontra arquivado, pretendia suspender a aplicação do parágrafo único do artigo $3^{\circ}$. e o artigo $4^{\circ}$., da Resolução do Conselho Federal de Psicologia (CFP), que determina as diretrizes de atuação para os psicólogos em relação ao tema da orientação sexual. A mudança seria em torno da Resolução $n^{\circ}$. 1/1999, onde o documento apresenta a seguinte redação:

Artigo $3^{\circ}$. - os psicólogos não exercerão qualquer ação que favoreça a patologização de comportamentos ou práticas homoeróticas, nem adotarão ação coercitiva tendente a orientar homossexuais para tratamentos não solicitados. Parágrafo único - Os psicólogos não colaborarão com eventos e serviços que proponham tratamento e cura das homossexualidades.

Artigo $4^{\circ}$. - Os psicólogos não se pronunciarão, nem participarão de pronunciamentos públicos, nos meios de comunicação de massa, de modo a reforçar os preconceitos sociais existentes em relação aos homossexuais como portadores de qualquer desordem psíquica.

Para o autor, ao delimitar as funções dos psicólogos e o direito da pessoa de obter orientação profissional, o CFP excedeu o seu poder regulamentar. Além disso, no momento da criação e restrição de direitos por meio da resolução $n^{\circ}$. 1/1999, a CFP apoderou-se de uma competência que cabe ao Poder Legislativo, atitude caracterizada, segundo o parlamentar, de abuso de poder regulamentar, trazendo implicações para o plano jurídico. Os seguintes excertos apontam a importância dada pelos deputados evangélicos ao tema na CDHM.

(...) o que esse projeto traz, na verdade, é um benefício ao direito humano de a pessoa escolher o que ela quer. Dep. Pastor Marco Feliciano, PSC - SP (Diário da Câmara dos Deputados, 04/06/2013, Sessão: 0661/13 / CDHM).

Se eu sou gay ou se eu não sou, se eu quero curar-me ou se eu não quero, é um problema meu, mas eu tenho o direito, sim, de procurar ajuda, se eu quiser. Se eu quiser, tem de haver alguém que possa 
ajudar-me. Eu não posso é ficar em conflito, eu não posso ficar sofrendo, eu não posso é ter problemas que vão acarretar, de repente, até a perda da vida. Deputada Liliam Sá, PR - RJ (Diário da Câmara dos Deputados, 04/06/2013, Sessão: 0661/13 / CDHM).

Os dois fragmentos citados demonstram a preocupação dos evangélicos em promover a alteração da resolução do CFP, na tentativa de criar mecanismos que permitissem a promoção de tratamentos oferecidos pelos psicólogos para curar a homossexualidade, ou seja, a cura gay para aqueles homossexuais que se encontram insatisfeitos com a sua orientação sexual e que pretendem mudá-la. Aprovada na CDHM, a alteração na resolução 1/1999 representaria "um retrocesso jurídico tendo em vista a resolução que vigora desde maio de 1990 da Organização Mundial de Saúde (OMS), que retirou a homossexualidade da lista internacional de doenças" (Marcelo TADVALD, 2015, p. 268). As terapias que promovem esse tipo de tratamento para a mudança de orientação sexual são apontadas pelas comunidades científicas de diversos países como prejudiciais, e também como uma forma de fomentar a discriminação e o preconceito, assim, pode-se dizer que o tema abordado no PDL 234/2011 não tem nada a ver com os direitos humanos.

O terceiro tema comentado na CDHM é a defesa da família. Assunto amplamente discutido pelos parlamentares evangélicos na comissão, a temática foi explorada por meio de diversos enfoques que dialogavam com os preceitos religiosos defendidos por esse segmento, ou seja, por intermédio da defesa da família tradicional, da família bíblica tradicional, da família cristã e também da família natural. De várias formas os membros da comissão tentaram inserir a pauta da família nas discussões, em especial, por meio da apresentação de proposições que mencionam a matéria, como demonstram os trechos a seguir:

(...) hoje a família brasileira está passando por algumas alterações. Nós precisamos lutar. Eu estou vendo até com muita simpatia a Igreja Católica fazendo um movimento muito grande em prol da família, assim como os evangélicos e todos os segmentos sociais. (...) Eu apresentei esse requerimento justamente para que a gente possa ver realizados os anseios da família brasileira, no que concerne a políticas públicas, ao apoio para que ela não se estilhace, para que, 
pelo contrário, a família reencontre-se e reforce-se para continuar o seu verdadeiro papel como célula-mãe da sociedade. (Dep Costa Ferreira, PSC - MA Diário da Câmara dos Deputados, 04/06/2013, Sessão: 0661/13 / (DHM.)

Nós que fazemos parte, certamente, da maioria aqui no Parlamento temos compromisso com a defesa da família tradicional, da família natural, da família cristã. Dep. João Campos, PSDB - GO (Diário da Câmara dos Deputados, 04/06/2013, Sessão: 0661/13 / CDHM).

O requerimento a que se refere o deputado Costa Ferreira é o REQ 44/2013, que propõe a realização de audiências públicas para discutir e apresentar propostas de iniciativa privada bem como a elaboração de políticas públicas voltadas para a valorização e proteção da família. O documento foi arquivado, porém, ocorreram diversas investidas procurando a inserção de discussões sobre a família nas demais pautas que tramitaram na CDHM durante a gestão de Feliciano. Muitas dessas tentativas foram baseadas em preceitos bíblicos, em mais uma tentativa de conduzir o religioso para o político, com o propósito de afirmar que todas as discussões que passam pela comissão, precisam levar em consideração a proteção e o fortalecimento da família, por esta ser considerada uma instituição divina, criada por Deus, que representa a origem da sociedade. Ocorre que, assim como o tema da contaminação por chumbo e o projeto da cura gay, a exploração da temática da família, na forma como é examinada e defendida pelos deputados evangélicos, pouco tem a ver com o que é historicamente discutido e apresentado na CDHM.

\section{CONSIDERAÇÕES FINAIS}

O episódio da escolha do pastor Marco Feliciano para a presidência da Comissão de Direitos Humanos e Minorias, em 2013, extrapolou os limites do Poder Legislativo e garantiu o seu espaço na opinião pública por intermédio da forte exposição nos meios de comunicação. A onda de protestos no Brasil contra a posse de Feliciano, através de palavras de ordem que tomaram as redes sociais, como o enunciado Feliciano não me representa, constitui um elemento indicativo da pertinência desse 
tema. É preciso observar que ocorreram também manifestações de apoio à permanência do parlamentar na presidência da CDHM, evidenciando dois polos antagônicos, munidos de justificativas características de seus campos de atuação, mais precisamente entre os argumentos laicos e confessionais, ou seja, opositoras/es e defensoras/es, respectivamente.

Este artigo demonstrou que a escolha de Feliciano para a presidência na CDHM representou um dos momentos de maior efervescência e polarização entre a maioria parlamentar evangélica e não evangélica no Congresso Nacional. Este trabalho apresentou, por meio da análise do discurso, as diferentes posições dos parlamentares nos momentos de construção dos argumentos de defesa e de crítica da posse do deputado evangélico, assim como as implicações que repercutiram no andamento dos trabalhos na comissão durante o mandato de Feliciano, em virtude da baixa produção legislativa, rejeição de matérias e inversão de pautas. Diante dos fatos polêmicos que circundaram a gestão de Feliciano, foi um período marcado por uma forte oposição dentro da CDHM, algo incomum desde a fundação da referida comissão.

Os conceitos de agonismo e antagonismo, verificados no trabaIho de Chantal Mouffe (2007, 2012, 2014), foram fundamentais para a análise discursiva, uma vez que serviram como categorias de análise para compreender a recorrência de um discurso religioso apoiado em preceitos morais. Em outras palavras, naqueles discursos oriundos de parlamentares evangélicos que buscavam estabelecer uma relação conflitiva entre o bem e o mal em torno das disputas que estavam sendo travadas na CDHM.

As observações de Chantal Mouffe, mais precisamente sobre o discurso moralista, foram essenciais para entender o desenvolvimento desse tipo de discurso, aqui representado pelo posicionamento das/ os evangélicas/os na CDHM. As consequências podem ser identificadas com a expansão desse fundamentalismo religioso na esfera legislativa, situação que favoreceu a perda da vitalidade da vida política, um vazio, conforme sugere Chantal Mouffe (2012), assim como a consequente ausência de formas de identificação democráticas.

O arcabouço dessas discussões evidenciou o acirramento das disputas em torno do nome de Feliciano na CDHM, como também a 
intensidade dos debates entre opositoras/es e defensoras/es em um ambiente hostil, na maioria das vezes. O discurso de defesa de Marco Feliciano possui como característica o estímulo de argumentos moralistas, pelo fato de que essas identidades religiosas, quando penetram na arena política, não apresentam uma disposição para o diálogo com os grupos antagônicos. A ação de parte desse segmento evangélico evidenciou uma postura sectária e intransigente, pouco aberta para o consenso no momento da posse de Marco Feliciano na CDHM.

\section{REFERÊNCIAS}

BIRMAN, Patrícia. Conexões políticas e bricolagens religiosas: questões sobre o pentecostalismo a partir de alguns contrapontos. In: SANCHIS, P. (Org.). Fiéis \& Cidadãos. Rio de Janeiro: Ed. UERJ, 2001, p. 59-86.

BURITY, Joanildo A. Discurso, política e sujeito na teoria da hegemonia de Ernesto Laclau. In: MENDONÇA, D.; RODRIGUES, L. P. (Orgs.). Pós-estruturalismo e teoria do discurso: em torno de Ernesto Laclau. Porto Alegre: EDIPUCRS, 2008, p. 35-51.

CAMPOS, Juliana Miranda Soares. Religião no Quilombo: Relações entre candomblecistas e evangélicos em Mangueiras (MG), 2012. Disponível em: <www.abant.org.br/ file?id=664>. Acesso em: 17 fev. 2016.

CASANOVA, José. Public Religions in the Modern World. Chicago: University of Chicago Press, 1994.

CHARAUDEAU, Patrick. Discurso político. São Paulo: Contexto, 2013.

DIÁRIO DA CÂMARA DOS DEPUTADOS. Nº. 53, 4 abr. 2013. Disponível em: http://imagem.camara.gov.br/Imagem/d/pdf/DCD04ABR2013.pdf\#page= Acesso em: 2 jun. 2016.

LACLAU, Ernesto. Nuevas reflexiones sobre la revolución de nuestro tiempo. Buenos Aires: Editora Nueva Visión, 1993.

LACLAU, Ernesto; MOUFFE, Chantal. Hegemonía y estrategia socialista: hacia una radicalización de la democracia. Madrid: Siglo XXI, 1987.

LEHMANN, David. Fundamentalismo y globalismo. Historia y política: Ideas, procesos y movimientos sociales. Madrid, n. 3, p. 81-120, 2000.

MOUFFE, Chantal. En torno a lo político. Buenos Aires: Fondo de Cultura Económica, 2007.

. La Paradoja democrática: El peligro del consenso en la política contemporánea. Barcelona: Gedisa editorial, 2012.

. El retorno de lo político: Comunidad, ciudadanía, pluralismo, democracia radical. Barcelona: Paidós, 2014. 
TADVALD, Marcelo. A reinvenção do conservadorismo: os evangélicos e as eleições federais de 2014. Debates do NER. Porto Alegre, v. 1, n. 27, p. 259-288, 2015.

VITAL DA CUNHA, Christina; LOPES, Paulo Victor Leite. Religião e política: uma análise da atuação de parlamentares evangélicos sobre direitos das mulheres e de LGBTs no Brasil. Rio de Janeiro: Fundação Heinrich Boll/ISER, 2012.

Submetido em: 29-09-2017

Aceito em: 16-11-2017 